\title{
Implementation of Al-Qur'an Memorization Program by Using Social Media in MA Sunan Giri Surabaya
}

\author{
Ismail $^{1}$, Abdul Muhid ${ }^{2}$ \\ Universitas Islam Negeri Sunan Ampel Surabaya \\ E-mail : 1ismailzulfa446@gmail.com, abdulmuhid@uinsby.ac.id
}

\begin{tabular}{|c|c|c|}
\hline Accepted: & Reviewed: & Published: \\
Jan 10th 2020 & March 5th 2020 & May,30th 2020 \\
\hline
\end{tabular}

\begin{abstract}
This study aims to describe the implementation of the Qur'an's tahfidz program by using social media at Senior Islamic High School of Sunan Giri Semampir Surabaya. The type of this research is a field research that the location is Senior Islamic High School of Sunan Giri as the executor of the Qur'an's memorizing extracurricular activities by looking for qualitative approach. The subject of this study involved the head of the school, the Trustees of the Qur'an memorizing program and participants of male and female students. Data collection using the method of observation, interviews and documentation. This Study uses the analytical method of Miles Huberman model with three steps, namely data reduction, data presentation, and drawing conclusions. The result of this research is: First, the Tahfidz Program in MA Sunan Giri Surabaya is a new program with memorization of 5 juz for students who stay in dormitory and 2 juz for non-boarding students. Second, the process of implementing memorization through social media, with 3 stages, namely: 1) Reading together verses to be memorized, 2) Memorizing students at their homes with the assistance of parents, 3) students' memorizes to the teacher through video calls. Third, the implementation of the Qur'an's memorizing program went well as expected as the program is usually in the school
\end{abstract}

Keywords: Qur'an Memorizing Program, Learning Media

\section{Pendahuluan}

Situasi Pandemi Covid 19 yang menyerang bumi telah membekukan seluruh aspek kehidupan, sekolah diliburkan, pasar ditutup, penerbangan distop, transportasi dibatasi. Dalam sektor pendidkan, kementerian pendidikan Indonesia resmi meliburkan sekolah sejak tanggal 16 Maret 2020. Sejak itu pula sekolah dilaksanakan di rumah, melalui perangkat internet, seperti google, medsos, ataupun media conference.

Situasi ini setidaknya mengajarkan kepada sekolah-sekolah untuk melaksanakan pembelajaran berbasi daring, yang disebut dengan E-Learning. E-Learning ialah proses pembelajaran dengan menggunakan media internet yang dapat menghubungkan siswa dan guru tanpa terbatas ruang dan waktu. Pembelajaran online ini telah merubah pola pembelajaran sekolah dimanapun. 
Salah satu nilai positifnya ialah hampir seluruh penduduk di Indonesia telah memiliki perangkat pembelajaran E-Learning, yakni Handphone. Berdasarkan riset dari We Are Social dalam detik.com dikabarkan bahwasanya pengguna internet di Indonesia pada tahun 2020 telah mencapai 175,4 juta, mengalami kenaikan 17\% atau 25 juta pengguna internet dari tahun berikutnya ${ }^{1}$. Maka tak heran jika menteri pendidikan mengambil tindakan untuk tetap menjalankan proses pembelajaran melalui daring (online) untuk setiap pelaksana pendidikan.

MA Sunan Giri sebagai salah satu pelaksana pendidikan di bawah KEMENAG turut menjalankan program pembelajaran melalui online, seperti dengan media google classroom, zoom, whats app dan media lainnya. Maka segala kegiatan pendidikan sepenuhnya dilaksanakan secara online, termasuk program tahfidul qur'an yang diselenggarakan di madrasah. Madrasah sendiri memiliki program unggulan yakni mencetak siswa yang dapat menghafalkan Al-Qur'an. Karena madrasah sendiri berada di bawah naungan Pondok Pesantren Tahfidzul Qur'an Sunan Giri Surabaya.

Peserta didik diharapkan tetap mampu menjalankan program tahfid di tengah situasi pandemi covid 19 ini. Dimulai dari hafalannya, pemberian motivasi, maupun setoran hafalan kepada guru pendamping yang sudah ditetapkan madrasah. Pola pembelajaran yang dilaksanakan ialah dengan penggunaan media whats app dan media zoom sebagai pengganti pertemuan antara guru dan murid. Berkat media yang sudah termutakhirkan, program tahfidzul qur'an di Madrasah Aliyah Sunan Giri bisa terlaksana dengan baik seperti yang diharapkan pengasuh.

Berkaitan dengan penjelasan di atas, sekiranya penulis mengira bahwa penting kiranya dilakukan penelitian tentang pelaksanaan program tahfidzul Qur'an melalu media social. Beberapa rumusan yang ingin diungkap yaitu : bagaimana pelaksanaan program tahfidz dengan media online sebagai pembelajaran E-Learning. Bagaimana efektifitas hafalan santri dengan melalui media dari.

\section{Tafidzul Qur'an}

1 https://inet.detik.com/cyberlife/d-4907674/riset-ada-1752-juta-pengguna-internet-di- indone sia diakses pada tanggal 18 Mei 2020 
Tabfidzul Qur'an adalah gabungan dari kata tabfidz dan Qur’an. Kata tahfidz ialah bentuk masdar dari haffaza, asal katanya hafidza-yahfad₹u, artinya menghafal. ${ }^{2}$ Kata hafiz. memiliki arti penekanan dan pengulangan pemelihara, dan kesempurnaannya. ${ }^{3}$ Sedangkan kata al-Qur'an merupakan Kalamullah yang diturunkan kepada Nabi Muhammad SAW melalui perantaraan malaikat Jibril yang ditilawahkan secara lisan, diriwayatkan kepada kita secara mutawattir. ${ }^{4}$

Tahfidz al-Qur'an dapat didefinisikan sebagai proses menghafal al-Qur'an dalam ingatan sehingga dapat dilafadzkan/ diucapkan di luar kepala secara benar dengan cara-cara tertentu secara terus menerus. Orang yang menghafalnya disebut al-hafiz, dan bentuk pluralnya adalah al-buffar: Definisi tersebut mengandung dua hal pokok, yaitu: pertama, seseorang yang menghafal dan kemudian mampu melafadzkannya dengan benar sesuai hukum tajwid harus sesuai dengan mushaf al-Qur'an. Kedua, seseorang penghafal senantiasa menjaga hafalannya secara terus menerus dari lupa, karena hafalan al-Qur'an itu sangat cepat hilangnya. ${ }^{5}$

Dewasa ini, program tabfid乏ul Qur`an banyak diminati untuk dikembangkan oleh lembaga-lembaga pendidikan baik formal maupun nonformal. Tentunya mengembangkan strategi pembelajaran tahfidzul Qur`an harus disesuaikan dengan terget penghafal. Strategi pembelajaran Tahfidzul Qur`an dikhususkan pada penggunaan metode-metode yang sesuai untuk menghafal al-Qur`an. Metode menghafal al-Qur`an, pada umumnya terdiri dari dua cara yaitu dengan cara menambah hafalan baru dan mengulang hafalan yang sudah ada, hal ini sebagaimana pernyataan H. A. Muhaimin Zen bahwa: "Metode menghafal al-Qur'an ada dua macam yang satu dengan yang lain tidak dapat dipisahkan, yaitu metode tahfidz dan takrir. Tahfidr: yaitu menghafal materi baru yang belum pernah dihafal. Takrir: Yaitu mengulang hafalan yang sudah diperdengarkan kepada instruktur". Masing-masing metode tersebut mempunyai kelebihan dan kekurangan yang dapat dibandingkan dalam proses pelaksanaannya. ${ }^{6}$

\footnotetext{
${ }^{2}$ Ibrahim Anis, Al-Mu'jam Al-W asit, (Mesir : Dar al-Ma'arif, 1392 H), 185

${ }^{3}$ M. Quraisy Syihab, Menyingkap Tabir Ilabi Al-Asma Al-Husna dalam Perspektif Al-Qur'an (Jakarta : Lentera Hati, 2006), 195

${ }^{4}$ M. Hasbi Ash-Shiddieqy, Sejarah dan Pengantar 'Ulum al-Qur'an/ Tafsir, (Jakarta: Bulan Bintang, 1992), 1

${ }^{5}$ Farid Wajdi, "Tahfîz al-Qur'an dalam Kajian 'Ulûm Al-Qur'an, (studi atas berbagai metode tahfîz)" dalam Tesis. (Jakarta: UIN Syarif Hidayatullah, 2008), 19

${ }^{6}$ Muhaimin Zen, Tata Cara / Problematika Menghafal al-Qur'an dan Petunjuk petunjuknya, (Jakarta: Pustaka alHusna, 1985 ), 225
} 
Adapun beberapa metode menghafal al-Qur`an yang dapat digunakan atau diimplementasikan di lembaga pendidikan formal maupun non formal menurut Khanifah, adalah sebagai berikut: ${ }^{7}$

1. Metode Sima'i

Metode sima'i, yaitu mendengarkan bacaan untuk dihafalkan dengan cara mendengar dari guru yang membimbing dan mengajarnya, merekam terlebih dahulu ayatayat yang akan dihafalkan ke dalam pita kaset sesuai dengan kebutuhan dan kemampuan secara seksama sambil mengikuti secara perlahan-lahan. Metode ini akan sangat efektif untuk penghafal tuna netra, anak-anak, atau penghafal mandiri atau untuk takrir (mengulang kembali) ayat-ayat yang sudah dihafalnya. Tentunya penghafal yang menggunakan metode ini, harus menyediakan alat-alat bantu secukupnya, seperti tape recorder, pita kaset dan lain-1ain.

\section{Metode Wahdah}

Metode wahdah adalah menghafal al-Qur`an dengan cara menghafal satu persatu ayat al-Qur`an. Untuk mencapai hafalan awal, setiap ayat bisa dibaca sebanyak sepuluh kali, atau dua puluh kali, atau lebih sehingga proses ini mampu membentuk pola dalam bayangan, akan tetapi hingga benar-benar membentuk gerak refleks pada lisannya. Setelah benar-benar hafal barulah dilanjutkan pada ayat- ayat berikutnya dengan cara yang sama. Demikian seterusnya hingga mencapai satu muka.Setelah ayat-ayat dalam satu muka telah dihafalnya, maka gilirannya menghafal urut-urutan ayat dalam satu muka.Untuk menghafal yang demikian maka langkah selanjutnya ialah membaca dan mengulang-ulang lembar tersebut hingga benar-benar lisan mampu mereproduksi ayat-ayat dalam satu muka tersebut secara alami atau refleksi. Demikian selanjutnya, sehingga semakin banyak diulang maka kualitas hafalan akan semakin representatif.

3. Metode Kitabah

Metode kitabah adalah menuliskan kembali ayat-ayat Al- Qur an yang sudah dihafal. Metode kitabah adalah menghafal dengan cara menulis ayatayat yang akan dihafalkan pada secarik kertas, kemudian ayat- ayat tersebut dibaca lalu dihafalkan. Pada metode ini siswa terlebih dahulu menulis ayatayat yang akan dihafalnya pada secarik kertas

\footnotetext{
${ }^{7}$ Nasokah, "Pembelajaran Tahfidzul Qur"an Pondok Pesantren Ulumul Qur"an Kalibeber Wonosobo," Jurnal Al- Qalam Vol.XIII. ISSN: 2356-2447- XIII, 2016, 230
} 
yang telah disediakan untuknya, kemudian ayat- ayat tersebut dibacanya sehingga lancar dan benar bacaannya, lalu dihafalkannya.

4. Metode Jama’ atau Jami

Menghafal al-Qur an dengan metode Jama’ adalah menghafal bersamasama yang dipimpin oleh seorang guru atau instruktur. Metode jama' yaitu menghafal secara kolektif, yakni ayat-ayat yang dihafal dibaca secara kolektif dipimpin oleh seorang instruktur.Setelah ayat-ayat itu dapat mereka baca dengan baik dan benar, selanjutnya mereka mengikuti bacaan instruktur dengan sedikit demi sedikit mencoba melepaskan $\mathrm{m}$ ushaf (tanpa melihat mushaf) dan demikian seterusnya sehingga ayat-ayat yang sedang dihafalnya itu benar-benar sepenuhnya masuk dalam bayangannya. Setelah siswa benarbenar hafal, barulah kemudian diteruskan pada ayat-ayat berikutnya dengan cara yang sama.

5. Metode Talqin

Metode talqin yaitu dengan cara guru membaca, kemudian santri menirukan dan jika salah dibenarkan oleh guru

6. Metode Muraja ah

Muraja'ah yaitu mengulang hafalan yang sudah diperdengarkan kepada guru atau kyai. Hafalan yang sudah diperdengarkan kehadapan guru atau kyai yang semula sudah dihafal dengan baik dan lancar, kadangkala masih terjadi kelupaan lagi bahkan kadangkadang menjadi hilang sama sekali. Oleh karena itu perlu diadakan Muraja'ah atau mengulang kembali hafalan yang telah diperdengarkan kehadapan guru atau kyai (Zawawie, 2011).Kegiatan muraja'ah merupakan salah satu metode untuk tetap memelihara hafalan supaya tetap terjaga. Allah berfirman dalam Al- Qur'an Surat AlBaqarah ayat 238 yang artinya:'Peliharalah semua shalatmu, dan peliharalah shalat wustha. Berdirilah untuk Allah (dalam shalatmu) dengan khusyu"'.

7. Metode Gabungan

Metode Metode gabungan yaitu menghafal al-Qur`an dengan cara menggabungkan dua metode atau lebih, misalnya metode sima'i dan kitabah, dan lain-lain. Metode gabungan merupakan gabungan antara metode pertama dan metode kedua, yakni metode wahdah dan metode kitabah atau dengan metode lainnya 


\section{Pembelajaran E Learning}

E-learning adalah teknologi informasi dan komunikasi untuk mengaktifkan siswa dalam belajar kapanpun dan dimanapun. Pembelajaran elektronik atau e-learning telah dimulai pada tahun 1970-an. Berbagai istilah digunakan untuk mengemukakan pendapat/gagasan tentang pembelajaran elektronik, antara lain adalah: onlinelearning, internet-enabled learning, virtual learning, atau web-based learning.Ada 3 (tiga) hal penting sebagai persyaratan kegiatan belajar elektronik (e-learning), yaitu: (a) kegiatan pembelajaran dilakukan melalui pemanfaatan jaringan, dalam hal ini dibatasi pada penggunaan internet, (b) tersedianya dukungan layanan belajar yang dapat dimanfaatkan oleh peserta belajar, misalnya External Harddisk, Flaskdisk, CD-ROM, atau bahan cetak, dan (c) tersedianya dukungan layanan tutor yang dapat membantu peserta belajar apabila mengalami kesulitan. ${ }^{8}$

E-learning dapat didefinisikan sebagai sebuah bentuk teknologi informasi yang diterapkan di bidang pendidikan dalam bentuk dunia maya. Istilah e-learning lebih tepat ditujukan sebagai usaha untuk membuat sebuah transformasi proses pembelajaran yang ada di sekolah maupun di perguruan tinggi ke dalam bentuk digital yang dijembatani teknologi internet. ${ }^{9}$ Sedangkan menurut Effendi terminologi e-learning sendiri dapat mengacu pada semua kegiatan pelatihan yang menggunakan media elektronik atau teknologi informasi. ${ }^{10}$

E-learning terdiri atas dua bagian yaitu "e" yang merupakan singkatan dari elektronik dan learning yang berarti pembelajaran. Jadi elearning berarti pembelajaran menggunakan jasa/bantuan perangkat elektronika, khususnya perangkat komputer. Karena itu e-learning sering disebut dengan on-line course. ${ }^{11}$

Satu ciri e-learning adalah adanya pembelajaran dengan kombinasi teknologi dan berbagai terapan praktis, serta dengan kesegeraan kemudahan akses sumber belajar, ke pengajar dan kesesama pembelajar, melalui internet. Fakta adanya kombinasi teknologi dengan terapan dalam pembelajaran e-learning juga dikemukakan oleh Savel yang menyatakan bahwa e-learning mengintegrasikan teknologi elektronik dan pendidikan, sebab itu penggunaan internet sangat dominan pada e-learning. ${ }^{12}$ Masih sejalan dengan hal diatas

8 S. Jaggi Dahiya, “An eLearning System for Agricultural Education”, Indian Research Journal of Extension Education, 12(3), 2016, 132

${ }^{9}$ Munir, Pembelajaran jarak, jaub berbasis Teknologi dan Informasi, (Bandung: CV Alfabeta, 2012), 169

${ }^{10}$ Empy Effendi, Hartono Zuang, E-learning Konsep dan Aplikasi, (Jakarta: Penerbit Andi, 2005), 6

${ }^{11}$ R Poppy Yaniawati, E-Learning dan Alternatif Pembelajaran Kontemporer, (Bandung: Arfino Raya, 2010), 73

${ }^{12}$ Ibid 
menurut Linde (2004), e-learning adalah pembelajaran secara formal Dan informal yang dilakukakan melalui media elektronik seperti: internet, intranet, CD-ROM, video tape, DVD, TV, Handphone, PDA, dan lain-lain

\section{Fungsi Pembelajaran Berbasis e-learning}

Setidaknya ada 3 (tiga) fungsi pembelajaran Berbasis E Learning terhadap kegiatan pembelajaran di dalam kelas yaitu sebagai suplement yang sifatnya pilihan/opsional, pelengkap (complement), atau pengganti (substitution). ${ }^{13}$

1. Tambahan (supplement)

Dikatakan berfungsi sebagai tambahan (supplement), apabila peserta didik mempunyai kebebasan memilih, apakah akan memanfaatkan materi pembelajaran elektronik atau tidak. Dalam hal ini, tidak ada kewajiban/ keharusan bagi peserta didik untuk mengakses materi pembelajaran elektronik. Sekalipun sifatnya opsional, peserta didik yang memanfaatkannya tentu akan memiliki tambahan pengetahuan atau wawasan.

2. Pelengkap (complement)

Dikatakan berfungsi sebagai pelengkap (complement) apabila materi pembelajaran elektronik diprogramkan untuk melengkapi materi pembelajaran yang diterima siswa di dalam kelas. Sebagai pelengkap berarti materi pembelajaran elektronik diprogramkan untuk menjadi materi pengayaan (reinforcement) atau perbaikan (remedial) bagi peserta didik di dalam mengikuti kegiatan pembelajaran konvensional.

3. Pengganti (substitution)

Beberapa sekolah/ perguruan tinggi di negara-negara maju memberikan beberapa alternatif model kegiatan pembelajaran/perkuliahan kepada para peserta didiknya. Tujuannya agar para peserta didik dapat secara fleksibel mengelola kegiatan perkuliahannya sesuai dengan waktu dan aktivitas lain sehari-hari mahasiswa. Ada 3 alternatif model kegiatan pembelajaran yang dapat dipilih peserta didik, yaitu: 1) Sepenuhnya secara tatap muka (konvensional) 2) Sebagian secara tatap muka dan sebagian lagi melalui internet, atau bahkan 3) Sepenuhnya melalui internet

13 Sudirman Siahaan, "E-Learning (Pembelajaran Elektronik) Sebagai Salah Satu Alternatif Kegiatan Pembelajaran”, Jurnal Pendidikan dan Kebudayaan, 2002, www.depdiknas.go.id 


\section{Metode Penelitian}

Penelitian ini merupakan penelitian deskriptif kualitatif, data didapatkan dengan cara observasi dan wawancara kepada pelaksana Tahfid melalui media daring. Juga sekaligus menanyakan kepada siswa mengenai pelaksanaan program tahfid tersebut.

Pengumpulan data penelitian ini menggunakan tiga metode, yaitu : observasi, wawancara, dan dokumentasi. Wawancara dilaksanakan dengan media social kepada pelaksana dan para siswa, Observasi ialah dengan mengikuti living chat di grup maupun menengok langsung proses hafalan antara pembimbing dan siswa. Dokumentasi didapatkan dengan melihat dokumen-dokumen MA Sunan Giri Surabaya

Dalam penelitian ini, teknik pegumpulan data menggunakan teori Miles dan Huberman. Proses analisis data menurut model Miles dan Huberman aktivitas dalam analisis data yaitu data reduction, data display, dan conclusion drawing/ verification.

Reduksi data adalah merangkum memilih hal-hal yang pokok, memfokuskan pada hal-hal yang penting dicari tema dan polanya. Dengan demikian data yang direduksi akan memberikan yang lebih jelas, dan mempermudah peneliti untuk melakukan pengumpulan data selanjutya, dan mencarinya bila diperlukan.

Data display atau penyajian data dalam penelitian kualitatif bisa dilakukan dalam bentuk uraian singkat, bagan, hubungan antar kategori, flowchart dan sejenisnya. Menurut Miles dan Hiberman (Sugiyono 2012:339) “the most frecuent form of display data for qualitative research data in the past has been narrative text'. Yang paling sering digunakan untuk menyajikan data penelitian kualitatif adalah dengan teks yang bersifat naratif.

Conclusion drawing verification adalah penarikan kesimpulan dan verifikasi. Kesimpulan dalam penelitian kualitatif adalah merupakan temuan baru yang sebelumnya belum pernah ada. Temuan dapat berupa diskripsi atau gambaran suatu objek yang sebelumnya masih remang-remang atau gelap sehigga setelah diteliti menjadi jelas, dapat berupa hubungan kasual atau interaktif, hipotesis atau teori.

\section{Pembahasan}

\section{Program Tahfid Al-Qur'an MA Sunan Giri}

MA Sunan Giri sebagai suatu madrasah yang berada di naungan PPTQ Sunan Giri menerima siswa dari berbagai kalangan. Siswa tidak hanya berasal dari pondok saja (tinggal di asrama pondok pesantren), sebagian lainnya ialah siswa di kawasan pondok pesantren 
(tidak mondok). Seperti diutarakan oleh Gus Ismal (kepala madrasah MA Sunan Giri) bahwa penerimaan siswa dari luar pondok pesantren ialah agar menambah jumlah kuantitas siswa madrasah yang masih berkembang. Meskipun begitu, ia tidak menampik keiinginan untuk memberlakukan kewajiban tinggal di asrama pondok pesantren untuk semua siswa, agar pendidikan bisa berjalan secara maksimal. Tetapi cita-cita itu menemui kendala, tidak semua siswa berkeinginan untuk mondok, dan juga terkendala tempat yang minim.

Mulanya siswa MA Sunan Giri tidak diwajibkan untuk menghafalkan Al-Qur'an. Hafalan Al-Qur'an hanya diwajibkan kepada siswa yang tinggal (muqim) di pondok pesantren. Pada tahun 2017, pengasuh meminta kepada kepala madrasah untuk mengupayakan kewajiban menyetorkan hafalan Al-Qur'an kepada seluruh siswa baik yang muqim ataupun yang tinggal di luar pondok, sebab madrasah ini berada di naungan pondok pesantren yang berkonsetrasikan tahfidz Al-Qur'an. Maka sekolah mewajibkan setoran hafalan Al-Qur'an sebanyak dua juz kepada siswa luar pondok, sedangkan untuk siswa yang tinggal di pondok diwajibkan menghafal lima juz. Untuk mensukseskan program tersebut, maka dilaksanakan program tahfidz mulai dari perencaan hingga proses evaluasi, sampai kepada peraturan wajib hafal Al-Qur'an yang ditargetkan sebagai prasarat kelulusan.

Kebijakan tahfidz Al-Qur'an sebagai prasarat kelulusan menuai pro-kontra dari beberapa wali murid. Sebagaimana diutarakan oleh Kamad, "Sebagian Wali murid tidak setuju dengan program hafalan Al-Qur'an ini, mereka beralasan anaknya disekolahkan bukan untuk tujuan tahfidz, tidak semua orang tua ingin anaknya menjadi hafid. Kami memberikan pemahaman kepada mereka tentang pentingnya menghafalkan Al-Qur'an bagi umat muslim, terutama siswa MA Sunan Giri, sehingga mereka menerimanya dengan legowo (lapang dada)".

Di sisi lain, program tahfidz di MA Sunan Giri justru mendapatkan dukungan dari wali murid yang lain. Sebagaimana wawancara peneliti dengan salah satu wali murid, bapak Abdul Rohim, “Itu (program tahfidz Al-Qur'an) sangat bagus sekali. Saya memang menyekolahkan anak saya di MA Sunan Giri untuk mendalami ilmu agama, terutama mempelajari Al-Qur'an dan hadits. Apalagi siswa dibimbing untuk menghafalkan AlQur'an oleh sekolah. Saya sangat mendukungnya. Karena masyarakat saat ini haus dengan agama. Alasan saya menyekolahkan anak saya di MA Sunan Giri daripada sekolah umum 
karena sekolah tersebut berada di lingkungan pondok pesantren. Dan kami kenal santrisantri sangat bagus dalam hafalan Al-Qur'an".

Madrasah sebagai suatu institusi yang dipasrahkan oleh wali murid, menjalankan tugasnya dengan baik. Madrasah tetap menjalankan program tahfidz Al-Qur'an sebagaimana diinstruksikan oleh pengasuh PPTQ Sunan Giri. Dalam menjawab sanggahan wali murid yang tidak setuju, pihak madrasah memberikan edukasi kepada siswa dan orang tuanya. Program ini bukan hanya tanggung jawab guru dalam mengawalnya, tetapi juga perlu kerja sama orang tua dalam mengawasi keberhasilan program.

Objek program ini terbagi ke dalam dua kelompok siswa, yakni siswa yang tinggal di pondok, dan siswa luar pondok. Target minimal keduanya berbeda, bagi siswa yang berstatus santri diwajibkan menghafalkan 5 juz, sedangkan siswa non santri diwajibkan menghafalkan 2 juz. Perbagian target ini cukup beralasan, sebab siswa yang berstatus santri lebih memiliki motivasi untuk menjadi hafiz. Maka sekolah tidak terlalu memberikan tugas yang memberatkan kepada siswa sesuai dengan kapasitas kemampuannya.

Dalam mensukseskan program tahfidz Al-Qur'an, Madrasah mensinergikan antara peserta didik, sekolah dan wali murid atau ustad/ah yang dari pesantren. Sebagaimana disampaikan ustad Subhi, selaku koordinator program tahfidz, "Di sekolah, anak-anak diberikan waktu untuk menghafalkan Al-Qur'an, yaitu sebelum jam pertama KBM dimulai, siswa juga dapat menyetorkan hafalannya kepada guru pendamping yang sudah ditentukan madrasah” . Madrasah memiliki 4 guru pendamping, yakni 2 ustadah untuk kelas putri, dan 2 ustad untuk kelas putra. Penjaringan guru pendamping melalui pertimbangan yang matang. Mereka adalah jajaran ustad/ah di Pondok Pesantren Tahfidzul Qur'an Sunan Giri. Tentunya hafalan mereka sudah matang, dan layak untuk membimbing siswa dalam program tahfidz.

Metode yang dilaksanakan oleh madrasah dalam menjalankan program tidak jauh berbeda dengan yang diterapkan di PPTQ Sunan Giri, dengan 3 metode, yaitu: metode wahdah, tahfidz, dan taqriri. Metode wahdah digunakan dengan cara menghafal satu persatu ayat, dibaca berkali-kali hingga hafal, baru bisa melanjutkan hafalan ke ayat berikutnya. Tahfidz yaitu menghafal materi baru yang belum pernah dihafal, dan 
diperdengarkan kepada guru. Taqriri digunakan mengulang-ngulang hafalan yang telah disetorkan kepada pembimbing.

Siswa yang muqim (tinggal) di pondok pesantren lebih mudah dalam pengawasannya, karena selama 24 jam sudah diatur kegiatannya oleh pengurus. Peneliti menilai bahwa setoran tahfidz bagi siswa berstatus santri adalah formalitas saja. Program tahfidz di madrasah lebih dikonsentrasikan kepada siswa dari luar pondok pesantren. Maka dalam pelaksanaannya, pihak madrasah juga melibatkan orang tua, dengan buku harian setoran materi hafalan siswa. Laporan nanti disetorkan lagi ke guru pembimbing.

Namun, pelaksanaan program ini membutuhkan bimbingan ekstra dari guru. Tidak semua siswa bisa membaca Al-Qur'an dengan baik, sesuai dengan tajwid dan lancar. Ustad Subhi menyampaikan, "Siswa yang belum bisa membaca Al-Qur'an dengan baik dikelompokkan, dan mendapatkan bimbingan khusus dalam membaca Al-Qur'an dan tahsin Al-Qur'an".

Program tahfidz dievaluasi pada setiap bulan, semester, dan tahunan, sesuai dengan target hafalan siswa. Siswa kelas X diberikan target hafalan 1 juz, siswa kelas XI diberikan target hafalan satu juz yang lain dari Al-Qur'an sesuai pilihan siswa, dan untuk siswa kelas XII dikhususkan untuk melancarkan hafalan kedua juz tersebut, sebelum akhirnya menjalani tes akhir tahfidz Al-Qur'an kepada koordinator program sebagari prasarat kelulusan. Sedangkan hafalan siswa yang berstatus santri memiliki target 5 juz.

\section{Pelaksanaan Tahfid dengan Media Sosial}

Adapun pelaksanaan pembelajaran di MA Sunan Giri di tengah situasi pandemi yang tidak menentu ini, menggunakan media daring sebagaimana diintruksikan oleh Kemendikbud agar tetap melaksanakan pembelajaran lewat media internet, umum disebut E Learning. Begitupun program tahfid Al-Qur'an di MA Sunan Giri tetap berjalan menggunakan media online, seperti whatsapp, google classroom, dan media zoom.

Pertama-tama, guru pembimbing membuat grup whats app khusus untuk program tahfid di setiap kelasnya, memberikan pengumuman bahwa kegiatan tahfid tetap berjalan seperti di sekolah biasanya dengan menggunakan media social.

Dalam tahap perencanaan, sebagaimana disampaikan oleh Ustad Subhi, selaku koordinator Program dengan wawancara online, bahwasanya pelaksanaan program tahfid tetap mengacu kepada metode yang dipakai di sekolah, dan Pondok Pesantren Tahfidz 
Al-Qur'an Sunan Giri, yaitu metode wahdah, tahfidz dan taqriri. Mulanya santri diwajibkan menghafalkan ayat Al-Qur'an ayat per ayat, bisa dilanjutkan jika telah menguasai dengan benar ayat yang sudah di hafal. Kemudian tetap mengulanginya di rumah masing-masing dengan pantauan orang tua. Dibuatkan buku laporan kepada orang tua agar mengawasi hafalan anaknya.

Mulai dari proses menghafal, guru pembimbing memberikan mengajak siswa untuk melafalkan bersama-sama, dengan media zoom yang menyediakan video conference. Guru membacakan ayat-ayat yang harus dihafalkan oleh siswa dengan bacaan tajwid yang baik dan benar, kemudia diikuti oleh siswa. Guru bisa mengecek cara bacaan siswa apakah sudah membaca Al-Qur'an sesuai dengan kaidah tajwid atau belum. Jika masih ada siswa yang masih kurang benar, guru pembimbing mengulanginya kembali hingga mendapat perbaikan. Di samping guru pembimbing membacakan ayat Al-Qur'an, dijelaskan pula makna ayat secara singkat agar siswa dapat menghafal dengan mudah disertai dengan penghayatan makna ayat yang dihafal. Guru pendamping juga memberikan motivasi tahfidul Qur'an untuk tetap memupuk semangat santri dalam menghafalkan Al-Qur'an

Guru pendamping di madrasah berjumlah 2 orang, yaitu ustad Subhi dan ustadah Zulfa. Ustad Subhi mendapat tanggung jawab dalam hafalan siswa laki-laki, sedangkan Ustadah Zulfa bagi siswa perempuan. Pembedaan guru pendamping yang sejenis ialah agar membuat pembelajaran lebih terfokus, dikhawatirkan ada mudorat dalam ketika melihat yang lawan jenis sehingga menggangu konsentrasi siswa ataupun guru. Sebagaimana disampaikan oleh Bapak Maulana, selaku Waka Kurikulum, "untuk kelas putra didampingi oleh Ustad Subhi, sedangkan untuk putri didampingi oleh Ustadah Zulfa, hal ini untuk membuat suasana lebih kondusif, dan menjauhi fitnah dalam menghafalkan Al-Qur'an.”

Setelah membacakan ayat Al-Qur'an di media conference secara bersama-sama maka setiap siswa diwajibkan untuk menghafalkannya, di waktu pagi dan sore hari. Agar bisa dipantau dengan baik oleh guru pemdamping, setiap siswa diwajibkan untuk mengupload laporan hafalan harian yang telah dibagikan disertai dengan tanda tangan orang tua. Seperti dikatakan Ustad Subhi, "Setiap siswa wajib menyetorkan laporan hafalan harian yang dipantau orang tua". Pelaksanaan demikian sesuai dengan metode yang digunakan madrasah dalam mengelola program tahfid, yakni dengan metode wahdah (menghafalkan ayat per ayat hingga hafal), tahfid. 
Selanjutnya ialah proses hafalan, yang mana siswa menyetorkan hafalan kepada guru pendamping dengan video call di media whatsapp. Setiap siswa yang sudah merasa bisa, menyetorkan hafalannya dengan bil ghaib (tanpa memegang Al-Qur'an) kepada guru pendamping. Guru pendamping menyimaknya, memperbaiki bacaan yang keliru dan apabila hafalan masih dirasa kurang lancar, maka siswa diharuskan untuk menghafalkannya kembali.

Dalam memantau hasil hafalan siswa, guru pendamping mengisi buku laporan hafalan siswa dalam menghafal Al-Qur'an. Buku laporan tersebut menjadi acuan penting di dalam proses evaluasi program, sejauh mana siswa dapat menghafalkan Al-Qur'an hingga kemudian dibenahi untuk kelanjutan program yang lebih baik ke depan.

Di akhir semester, setiap siswa menyetorkan hafalannya kepada guru pendamping sesuai target. Adapun targetnya ialah siswa dapat menghafalakan Al-Qur'an berjumlah 1 juz setiap tahunnya. Jika satu tahun ada dua semester, maka target hafalan tiap semester ialah setengah juz. Seperti diutarakan oleh Ustad Subhi, "semua siswa wajib menyetorkan hafalan sesuai target di akhit semester." Tentunya di tengah pandemic ini, setoran hafalan menggunakan media whats app melalui video call siswa dan guru pendamping.

\section{Efektifitas program tahfid dengan media social}

Sebuah program dinyatakan berhasil jika memenuhi kriteria target perencanaan. Adapun target hafalan siswa MA Sunan Giri ialah dapat meghafalkan 2 juz bagi siswa luar pondok, dan 5 atau 6 juz bagi siswa yang muqim di pondok. Maka demi tercapainya target keseluruhan, program hafalan dibagikan di setiap semesternya. Target semester, siswa dapat menghafal setengah juz bagi siswa non-pesantren, dan setoran 2 juz untuk siswa berstatus santri.

Pada sub bab ini, peneliti ingin mengetahui respon siswa dan guru pendamping dalam pelaksanaan program tahfid dengan media sosial, karena ini adalah pola baru di tengah pandemi yang belum berakhir. Peneliti mengajukan pertanyaan kepada guru pendamping, apakah program tahfid berjalan dengan baik di media social? Apakah siswa dapat menghafalkan Al-Qur'an dengan baik dan menyetorkannya sesuai harapan?. Sedangkan beberapa pertanyaan yang perlu dijawab oleh siswa, apakah siswa nyaman dengan program tahfid melalui whats app tersebut? Apakah siswa bisa menghafalkan alQur'an dan menyetorkannya dengan baik? Apa kendala dan kelebihan yang didapatkan 
dengan penggunaan media social ini kepada siswa maupun yang dialami guru pendamping?

Pertama, ialah wawancara yang dilakukan kepada guru pendamping dari peneliti melalui whats app. Ustad Subhi menjelaskan bahwa meskipun sekolah diliburkan, program tahfid tetap berjalan sesuai yang diinginkan. Katanya, "Alhamdulillah program tahfid dengan media social terlaksana degan baik"

Pendapat tersebut diaminkan oleh Ustadah Zulfa, selaku guru pendamping putri, "Dengan adanya media social yang canggih, kita bisa melakukan segala hal tanpa terbatas ruang dan waktu, termasuk menghafalkan Al-Qur'an”. Dikabarkan dari keduanya, justru pelaksanaan program tahfid dengan media social ini lebih efisien. Meskipun tetap ada kendala-kendala yang dirasakan, seperti minimnya kuota yang dimiliki, atau beberapa siswa tidak memiliki perangkat yang support untuk aplikasi media social.

Sedangkan proses setoran siswa kepada guru pendamping, dilaksanakan dengan baik. Sebagaimana disampaikan oleh Ustad Subhi, "kami menelpon siswa satu persatu untuk mengecek hafalannya, hingga hafalannya baik dan lancar". Setoran melalui whats app tidak jauh bedanya dengan setoran di madrasah, dimana guru pendamping bisa menyimak dengan baik hafalan santri, dan mengetahui kelebihan dan kekurangan hafalan. Maka proses setoran hampir tidak menemui kendala, kecuali kuota yang mungkin diperlukan cukup banyak.

Adapun dari segi siswa, diharapkan program hafalan dinikmati dengan baik oleh siswa. Suatu pembelajaran atau pelaksanaan dikatakan baik jika memberikan efek riang dan gembira dan tidak terlalu memberatkan kepada siswa. Sehingga siswa dapat mengikuti program tanpa beban dan dapat mencapai target.

a. Dapat melaksakan hafalan dengan baik

Meskipun sekolah diliburkan, siswa mengakui tetap melaksanakan pembelajaran di rumah dengan media social. Seperti diujarkan oleh Afika, "Kami tetap belajar di rumah, menghafalkan di rumah, dan tetap bisa berkomunikasi dengan guru dan teman-teman lainnya". Begitupula disampaikan oleh Muyassaroh, "Covid tidak membuat kami lemah, dan malas belajar, saya jadi bisa menggunakan hp saya untuk belajar daripada bermain game atau social media yang kurang manfaat".

Ketika ditanya apakah siswa tetap bisa menghafalkan Al-Qur'an dengan baik, siswa menyetujui video conference yang dilakukan guru pendamping untuk membaca 
lalu menjelaskan makna disertai motivasi. Seperti dikatakan Ali Wafa, "Setelah mendengarkan bacaan secara bersama-sama dengan aplikasi zoom, kami menghafalkannya sebagaimana disampaikan guru untuk menghafalkan ayat Al-Qur'an setelah sholat wajib".

b. Perasaan gembira dalam program tahfid online

Suatu program dikatakan berjalan dengan baik apabila peserta didik menikmatinya, dan tidak merasa keberatan dengan metode yang dipakai. Hafalan ataupun setoran hafalan mendapatkan respon positif dari para siswa. Sebagaimana dikatakan oleh Nisa, "Saya senang bisa belajar dengan media social, kami bisa bertatap muka di media social kepada guru dan teman teman lainnya." Begitu pula disampaikan oleh Umam, "Libur sekolah membuat kami merasa rindu untuk sekolah, Alhamdulillah kami masih bisa bersilaturrahmi denga guru dan teman-teman dengan video conferece".

Pelaksanaan program tahfid yang dilakukan via online mendapat respon positif dari siswa. Tentunya diharapkan siswa bisa menghafalkan Al-Qur'an dengan baik, dengan pantauan langsung oleh orang tua. Dan juga siswa dapat menyetorkan hafalannya dengan baik. Muhaimin mengatakan, "ketika kami menyetor hafalan, kami telfon pribadi ustad, dan menyetorkannya, kami merasa dekat dengan beliau".

c. Terkendala dengan paket dan kuota

Tidak hanya guru yang mendapatkan kendala kuota dalam pelaksanaan media online. Media social dan video conference telah mengrus kuota siswa dalam pelaksanaan pembelajaran. Seperti dikatakan Afika, "tidak terasa kuota paket saya cepat habis dengan adanya pembelajaran online". Hal ini juga diaminkan Muyassaroh, "Jika digunakan untuk video conference, cukup lumayan menghabiskan kuota, tak seperti chat di media social".

Maka untuk mengatasi problem ini, sekolah perlu melakukan terobosan dengan memberikan jaminan kuota di setiap bulannya kepada setip siswa, minimal subsidi untuk membeli pulsa paket internet. Bagaimana program bisa berjalan dengan baik jika media yang dipakai masih terkendala dan tidak bisa terkoneksi ke internet. Kuota menjadi hal yang sangat mendasar dalam pelaksanaan pembelajaran online utamanya hafalan santri. 


\section{Kesimpulan}

Dari penelitian ini, bisa disimpulkan dalam beberapa hal :

Pertama, Program Tahfid di MA Sunan Giri Surabaya merupakan program baru yang diamanahkan pengasuh PPTQ (Pondok Pesantren Tahfidz Al-Qur'an). Adapun target hafalannya terbagi kepada 2 kelompok, 1) Siswa berstatus santri dapat menghafap 5 atau 6 juz, 2) siswa non pesantren menghafal 2 juz. Pelaksanaan tahfid menggunakan metode wahdah, tahfid, dan taqrir.

Kedua, pelaksanaan program tahfid melalui media sosial ialah dengan aplikasi whats app, dan media zoom untuk memenuhi video conference. Dibentuknya grup whats app khusus program tahfid untuk setiap kelas, yang dipantau oleh guru pembimbing. Proses pelaksanaan tahfid melalui 3 tahap, yakni: 1) Membaca bersama-sama ayat yang akan dihafal, dengan dipandu guru pembimbing melalui media zoom, 2) Hafalan siswa di rumah masingmasing dengan dibuktikan tanda tangan orang tua di buku laporan harian dan diupload di grups whats app, 3) Setoran hafalan siswa kepada guru pembimbing dengan menggunakan aplikasi telefon di whats app

Ketiga, Pelaksanaan program tahfidzul qur'an berjalan dengan baik seperti yang diharapkan. Guru bisa memberikan pendampingan melalui media sosial dengan begitu bersemangat. Siswa dapat mengikuti program yang dipandu oleh guru pendamping. Mereka merasa senang dan gembira dengan program tahfid online ini. Adapun kendala yang dirasaka guru dan siswa ialah kuota yang dibutuhkan cukup besar.

\section{Daftar Pustaka}

Anis, Ibrahim dkk. Al-Mu’jam Al-Wasit. Mesir: Dar al-Ma'arif, 1392 H

Ash-Shiddieqy, M. Hasbi. Sejarah dan Pengantar 'Ulum al-Qur'an/Tafsir. Jakarta: Bulan Bintang, 1992

Dahiya, S. Jaggi. “An e-Learning System for Agricultural Education”. Indian Research Journal of Extension Education. 2016

Effendy, Empy, Hartono Zhuang. E-Learning, Konsep dan Aplikasi. Yogyakarta: Penerbit ANDI, 2005

Munir. Pembelajaran jarak jaub berbasis Teknologi dan Informasi. Bandung: CV Alfabeta, 2012

Nasokah, A \& Ahmad Khori. "Pembelajaran Tahfidzul Qur"ean Pondok Pesantren Ulumul Qur'an Kalibeber Wonosobo”. Jurnal Al- Qalam Vol.XIII, 2014 
Siahaan, Sudirman. "E-Learning (Pembelajaran Elektronik) Sebagai Salah Satu Alternatif Kegiatan Pembelajaran”. Jurnal Pendidikan dan Kebudayaan, www.depdiknas.go.id, 2002

Syihab, M. Quraisy. Menyingkap Tabir Ilabi Al-Asma Al-Husna dalam Perspektif Al-Qur'an. Jakarta : Lentera Hati, 2006

Wajdi, Farid. “Tahfîz al-Qur'An dalam Kajian 'Ulûm Al-Qur'an (studi atas berbagai metode tahfîz)". Tesis. Jakarta: UIN Syarif Hidayatullah, 2008

Yaniawati R Poppy. E-Learning dan Alternatif Pembelajaran Kontemporer. Bandung: Arfino Raya, 2010

Zawawie, Mukhlisoh. Al-Qur'an: Pedoman Membaca, Mendengar, dan Menghafal Al-Qur'an. Solo: PT Tiga Serangkai Pustaka Mandiri, 2011

Zen, Muhaimin, 1985 Tata Cara /Problematika Menghafal al-Qur'an dan Petunjuk petunjuknya, Jakarta: Pustaka al-Husna, 